\title{
Therapeutic targets and limits of minocycline neuroprotection in
} experimental ischemic stroke

\author{
Noriyuki Matsukawa ${ }^{1}$, Takao Yasuhara ${ }^{1}$, Koichi Hara ${ }^{1}$, Lin Xu${ }^{1}$, Mina Maki ${ }^{1}$, \\ Guolong Yu${ }^{1}$, Yuji Kaneko ${ }^{1}$, Kosei Ojika ${ }^{2}$, David C Hess ${ }^{1}$ and \\ Cesar V Borlongan*1,3
}

Address: ${ }^{1}$ Department of Neurology, Medical College of Georgia, Augusta, GA 30912, USA, ${ }^{2}$ Department of Neurology and Neuroscience, Nagoya City University Graduate School of Medical Sciences, Nagoya, 467-8601, Japan and ${ }^{3}$ Research and Affiliations Service Line, Augusta VAMC, Augusta, GA 30912, USA

Email: Noriyuki Matsukawa - norim@med.nagoya-cu.ac.jp; Takao Yasuhara - tyasu37@cc.okayama-u.ac.jp; Koichi Hara - khara@sc.itc.keio.ac.jp; Lin Xu - xulin88@yahoo.com; Mina Maki - rminamaki@gmail.com; Guolong Yu - yuguolong123@yahoo.com.cn; Yuji Kaneko - ykaneko@health.usf.edu; Kosei Ojika - kojika@med.nagoya-cu.ac.jp; David C Hess - dhess@mail.mcg.edu; Cesar V Borlongan* - cborlong@ health.usf.edu

* Corresponding author

Published: 6 October 2009

BMC Neuroscience 2009, 10:126 doi:10.1/86/1471-2202-10-126
Received: 24 February 2009

Accepted: 6 October 2009

This article is available from: http://www.biomedcentral.com/I47I-2202/I0//26

(c) 2009 Matsukawa et al; licensee BioMed Central Ltd.

This is an Open Access article distributed under the terms of the Creative Commons Attribution License (http://creativecommons.org/licenses/by/2.0), which permits unrestricted use, distribution, and reproduction in any medium, provided the original work is properly cited.

\begin{abstract}
Background: Minocycline, a second-generation tetracycline with anti-inflammatory and antiapoptotic properties, has been shown to promote therapeutic benefits in experimental stroke. However, equally compelling evidence demonstrates that the drug exerts variable and even detrimental effects in many neurological disease models. Assessment of the mechanism underlying minocycline neuroprotection should clarify the drug's clinical value in acute stroke setting.

Results: Here, we demonstrate that minocycline attenuates both in vitro (oxygen glucose deprivation) and in vivo (middle cerebral artery occlusion) experimentally induced ischemic deficits by direct inhibition of apoptotic-like neuronal cell death involving the anti-apoptotic Bcl-2/ cytochrome c pathway. Such anti-apoptotic effect of minocycline is seen in neurons, but not apparent in astrocytes. Our data further indicate that the neuroprotection is dose-dependent, in that only low dose minocycline inhibits neuronal cell death cascades at the acute stroke phase, whereas the high dose exacerbates the ischemic injury.

Conclusion: The present study advises our community to proceed with caution to use the minimally invasive intravenous delivery of low dose minocycline in order to afford neuroprotection that is safe for stroke.
\end{abstract}

\section{Background}

Cerebral ischemia triggers a cascade of pathophysiological events including excitotoxicity, ionic imbalance, oxidative and nitrosative stresses and apoptotic-like cell death mechanisms [1-8]. To date, the thrombolytic agent tPA is the only effective drug for acute ischemic stroke; however, only about $2 \%$ of ischemic stroke patients benefit from this treatment due to its limited therapeutic window [9]. There is a desperate need to develop additional neuroprotective strategies [10-12]. Minocycline is a promising neuroprotectant because if is safe, easily penetrates the CNS, and effective in various models of acute neurological injury. 
Cell death associated with the initial blood flow interruption and the immediately ensuing excitotoxity is abrupt, while inflammation occurs over a long period of time from stroke onset. Accordingly, anti-inflammatory treatment is likely to extend the therapeutic window allowing improved intervention in stroke. Indeed, minocycline, a common tetracycline antibiotic, has been demonstrated to provide neuroprotection against ischemic brain via the inhibition of the inflammatory cascade [13-15]. Accumulating evidence indicates that minocycline exerts neuroprotective effects in neurodegenerative disease models, such as Parkinson's disease, Alzheimer's disease, multiple sclerosis, spinal cord injury, and Huntington's disease [16-24]. Depending on the experimental injury paradigm [19], minocycline may promote neuroprotection through inhibition of microglial activation via p38 against NMDA excitotoxicity [25] ischemic injury [26], NO [27], glutamate [28] and MPTP excitotoxicity [17], or through suppression of apoptotic cell death via Bcl-2/cytochrome c against ischemia in kidney cells [29], heat stress in testes [30], and NO excitotoxicity in vascular smooth muscle [31], spinal cord injury [32] and ALS [33]. In animal models of stroke, minocycline has been reported to reduce infarct volume and to attenuate behavioral deficits [34-37] via the inhibition of microglial activity [13-15]. Overall, the commonly postulated pathway of minocycline neuroprotection in stroke focuses on the modulation of microglial activity. However, because the acute stage of stroke involves abrupt neuronal injury prior to inflammatory reaction, the demonstration of minocycline protection against the primary ischemic cell death would be of high therapeutic interest. Moreover, whereas the inhibition of microglial activity by minocycline against ischemia has been shown to highly correlate with the dose [15,34-40], the possibility of neurotoxicity of minocycline at higher doses has only been recently recognized [41,42].

In this study, we examined direct protective effects of minocycline on neurons and astrocytes, and also determined minocycline's toxicity profile in both in vitro and in vivo models of stroke. The overarching theme is to provide guidance on advancing minocycline therapy to the clinic by assuring the safety of the drug and further understanding the feasibility of a direct neuroprotective treatment in view of the acute cell death associated with ischemic stroke.

\section{Results \\ Minocycline improves cell viability of neurons, but not astrocytes}

Based on ATP activities (MTT assay), minocycline, at low doses, maintained cell viability of primary cultured neurons exposed to OGD $(0.001 \mu \mathrm{M}$ : $85.9 \pm 13.1 \%, 0.01 \mu \mathrm{M}$ : $94.4 \pm 7.2 \%, 0.1 \mu \mathrm{M}: 90.4 \pm 13.0 \%, 1 \mu \mathrm{M}: 88.2 \pm 13.8 \%$; values hereon are expressed relative to non-OGD exposed group) compared to vehicle treated group $(0 \mu \mathrm{M}: 67.1 \pm$ $10.3 \%)$, but was toxic at high dose $(100 \mu \mathrm{M}: 55.1 \pm 8.4 \%)$ $\left(\mathrm{F}_{7,32}=14.775, \mathrm{p}<0.0001\right)$ (Figure $\left.1 \mathrm{~A}\right)$. In contrast, minocycline, at all doses, did not exert neuroprotective effects on primary cultured astrocytes, and additionally was toxic at high dose $(100 \mu \mathrm{M}: 49.5 \pm 5.0 \%)$ compared to vehicle-treated group $(0 \mu \mathrm{M}: 72.6 \pm 4.3 \%)\left(\mathrm{F}_{7,32}=\right.$ 16.255, p < 0.0001) (Figure 1B). Similarly, Trypan blue results mimicked those of MMT data, in that cell viability of neurons, but not astrocytes, was maintained by low doses of minocycline (neurons: $0.01 \mu \mathrm{M}$ : $66.6 \pm 10.9 \%$, $0.1 \mu \mathrm{M}: 87.6 \pm 2.9 \%, 1 \mu \mathrm{M}: 77.3 \pm 8.2 \%$ ), while high dose minocycline was toxic to both neurons and astrocytes (neurons: $100 \mu \mathrm{M}$ : $10.5 \pm 4.7 \%$; astrocytes: $100 \mu \mathrm{M}$ : 43.3 $\pm 7.7 \%$ ) compared to vehicle-treated group (neurons: 0 $\mu \mathrm{M}: 56.3 \pm 6.9 \%, \mathrm{~F}_{7,32}=57.300, \mathrm{p}<0.0001$, astrocytes: 0 $\mu \mathrm{M}: 43.3 \pm 7.7 \%, \mathrm{~F}_{7,32}=27.989, \mathrm{p}<0.0001$ ) (Figure 1C$\mathrm{L})$.

\section{Minocycline alters OGD-induced apoptotic cell death}

The cell death of neurons and astrocytes under OGD condition represents apoptotic-like cell damage as revealed by caspase 3/7 assay (neurons: 29927.5 \pm 6365.4 /well; astrocytes: $17758.5 \pm 5.78 .9$ well) (Figure 2A, B) and TUNEL assay (neurons: $189.6 \pm 18.8$ cells $/ 0.2 \mathrm{~mm}^{2}$; astrocytes: $60.7 \pm 2.8$ cells $/ 0.2 \mathrm{~mm}^{2}$ ) (Figure 2I, J). Compared to normal, non-OGD conditions, OGD increased caspase activity levels by about 1.5 -fold. Treatment with low dose minocycline prevented such apoptotic-like cell death in neurons characterized by reduced caspase $3 / 7$ activity (neurons: $16675.8 \pm 2474.2 /$ well $)\left(F_{2,12}=19.611 ; \mathrm{p}=\right.$ 0.0002 ) (Figure $2 \mathrm{~A}$ ) and decreased TUNEL positive cells $\left(55.0 \pm 13.2\right.$ cells $\left./ 0.2 \mathrm{~mm}^{2}\right)\left(\mathrm{F}_{2,12}=13.26 ; \mathrm{p}<0.001\right)$ (Figure $2 \mathrm{C}-\mathrm{E}, \mathrm{I})$. However, protective effects of low dose minocycline were not detected in astrocytes (caspase: 22705.9 \pm 2268.0 /well, TUNEL: $83.7 \pm 4.544$ cells $/ 0.2 \mathrm{~mm}^{2}$ ) (Figure $2 \mathrm{~B}, \mathrm{~F}-\mathrm{H}, \mathrm{J})$. Moreover, minocycline, at a high dose, worsened apoptotic-like cell death in both neurons (caspase: $35600.0 \pm 3450.4 /$ well), (TUNEL: $234.0 \pm 33.7$ cells/well) and astrocytes (caspase: $30708.0 \pm 2901.3 /$ well) $\left(\mathrm{F}_{2,12}=9.831 ; \mathrm{p}=0.0030\right)$, (TUNEL: $75.8 \pm 10.5$ cells $\left./ 0.2 \mathrm{~mm}^{2}\right)\left(\mathrm{F}_{2,12}=4.76 ; \mathrm{p}<0.01\right)$ (Figure $\left.2 \mathrm{~A}, \mathrm{~B}, \mathrm{I}, \mathrm{J}\right)$.

Under OGD condition, increased Bcl-2 expression was induced by low dose minocycline in cultured neurons $(0$ $\mu \mathrm{M}: 1.25 \pm 0.48,1 \mu \mathrm{M}: 18.9 \pm 2.16$ cells $\left./ 0.05 \mathrm{~mm}^{2}\right)$, but not at a high dose $\left(100 \mu \mathrm{M}: 2.21 \pm 1.10\right.$ cells $\left./ 0.05 \mathrm{~mm}^{2}\right)$ $\left(\mathrm{F}_{2,12}=15.288 ; \mathrm{p}=0.004\right)$ (Figure 3A-D, H). In contrast, Bcl-2 expression was not altered by minocycline at all doses in astrocytes $(0 \mu \mathrm{M}: 3.33 \pm 2.11,1 \mu \mathrm{M}: 1.67 \pm 1.67$, $100 \mu \mathrm{M}: 0.0 \pm 0.0$ cells $/ 0.05 \mathrm{~mm}^{2}$ ) (Figure $\left.3 \mathrm{~A}, \mathrm{E}-\mathrm{G}, \mathrm{I}\right)$. In parallel, the OGD-induced release of cytochrome $\mathrm{c}$ from mitochondria into cytosol was prevented by minocycline at a low dose in neurons. 

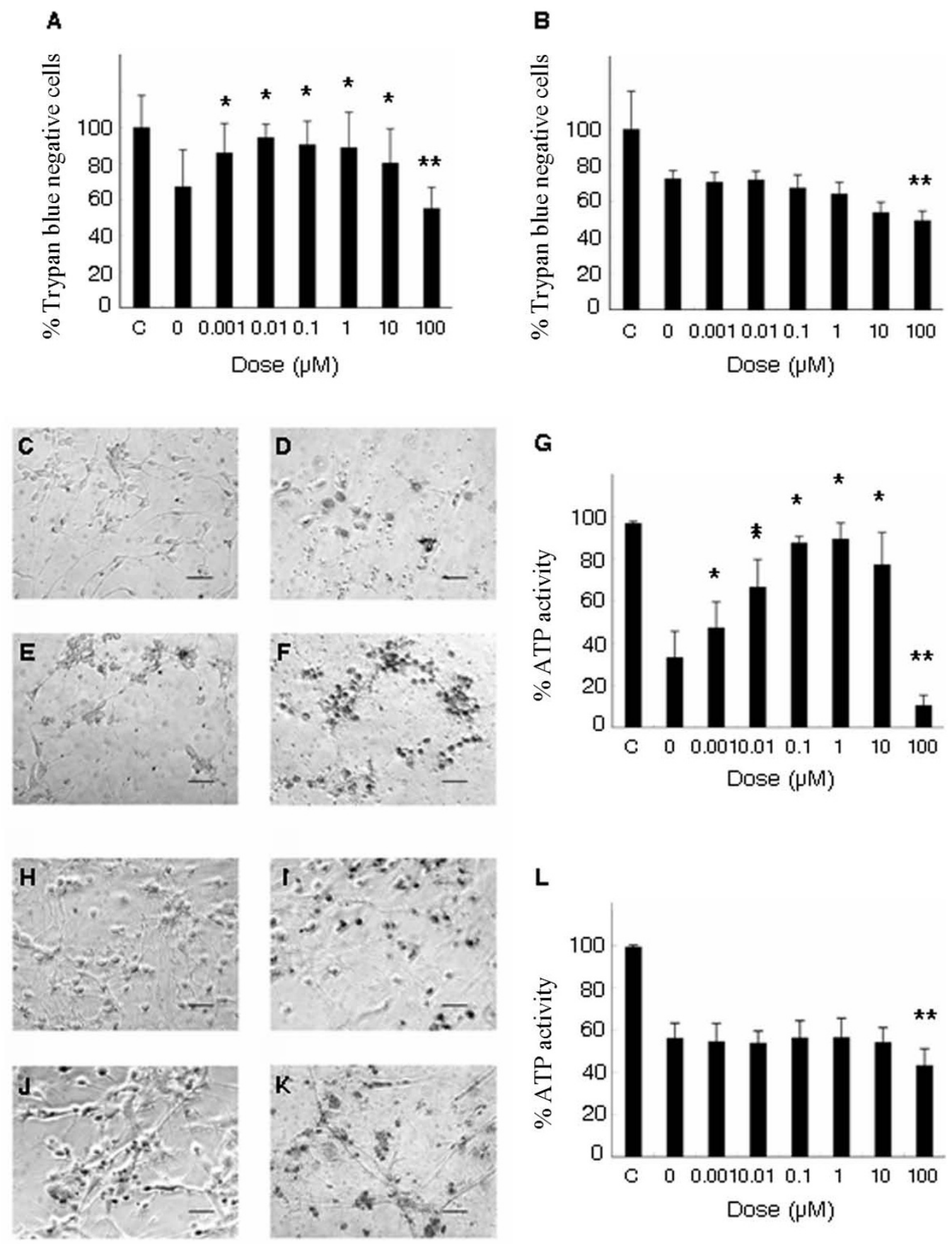

Figure I

ATP activity and trypan blue assay in cultured neurons and astrocytes. ATP activity was measured to reveal cell viability with varying concentrations of minocycline or vehicle. OGD condition reduced ATP activity of cultured neurons to $40 \%$ of non-OGD control group $(A)$. Low doses of minocycline $(0.001$ to $10 \mu \mathrm{M})$ preserved cell viability of neurons $(A)$, but not astrocytes (B). In contrast, high dose of minocycline (100 $\mu \mathrm{M})$ displayed toxicity to both neurons and astrocytes (A, B). In parallel with ATP assay, Trypan blue assay revealed that low doses of minocycline $(0.00 \mathrm{I}-10 \mu \mathrm{M})$ exerted neuroprotective effects on cultured neurons, but not astrocytes (C-G: neurons, $\mathrm{H}$-L: astrocytes, $\mathrm{C}, \mathrm{H}$ : non-OGD control, D, I: $0 \mu \mathrm{M}, \mathrm{E}, \mathrm{J}$ : I $\mu \mathrm{M}, \mathrm{F}, \mathrm{K}$ : $100 \mu \mathrm{M}$ of minocycline). High dose of minocycline $(100 \mu \mathrm{M})$ displayed toxicity for both neurons and astrocytes. Data are shown as mean values \pm SEM $\left(* \mathrm{p}<0.05\right.$ increase and $*^{*} \mathrm{p}<0.05$ decrease vs. vehicle-treated cultured neurons or astrocytes; $A$, G: neurons, B, L: astrocytes). Scale bar: $25 \mu \mathrm{m}$. 

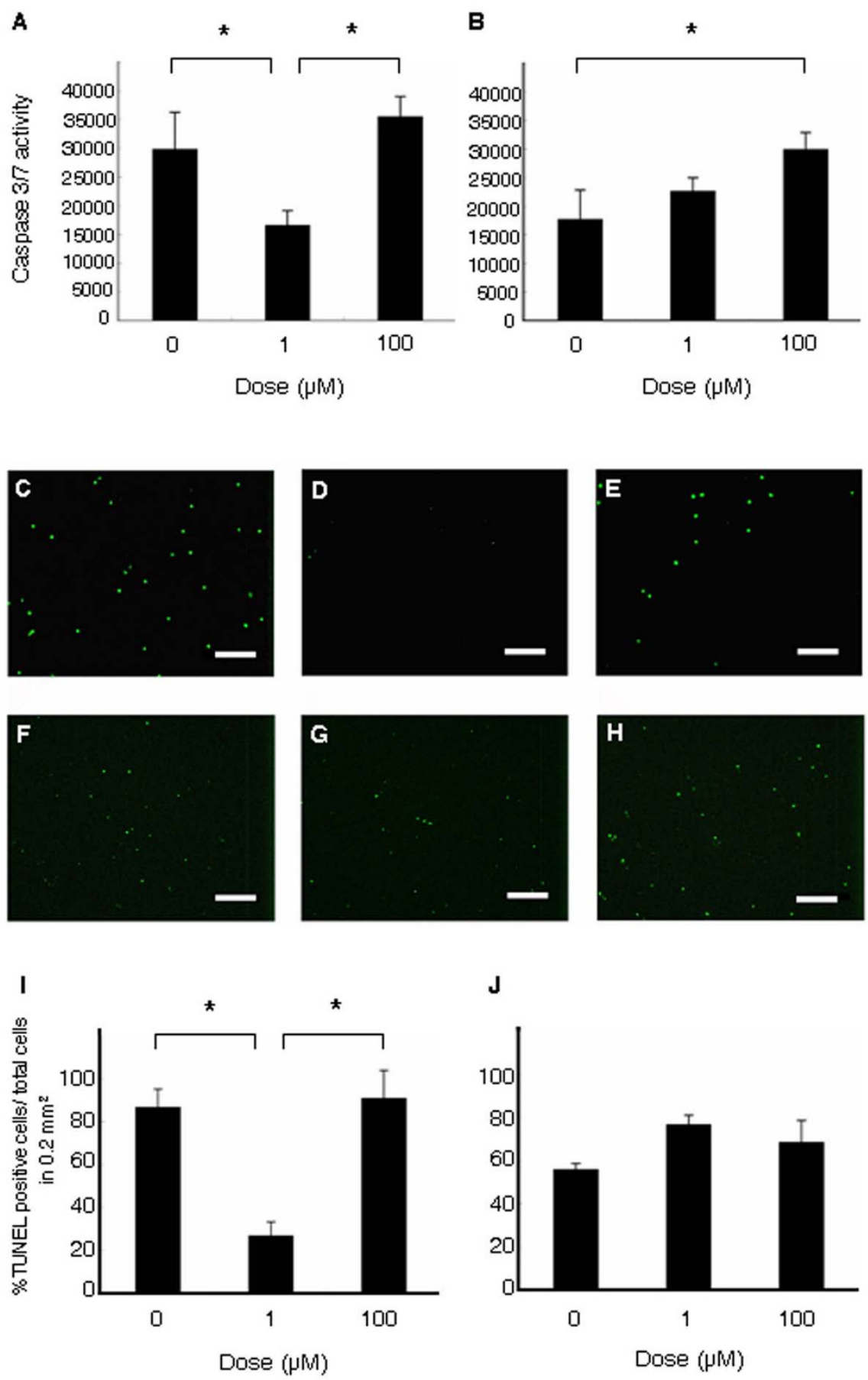

Figure 2

Caspase $3 / 7$ activity and tunel staining in cultured neurons and astrocytes. Low dose minocycline $(I \mu M)$ reduced caspase $3 / 7$ activity of neurons (A), but not of astrocytes (B). In contrast, high dose minocycline (I00 $\mu$ M) displayed no suppressive effects on caspase $3 / 7$ activity of neurons and increased that of astrocytes (A, B). Similarly, low dose minocycline reduced, whereas high dose minocycline increased the number of TUNEL positive neurons compared to vehicle-treated cultured neurons (OGD-exposed neurons treated with 0 , I and $100 \mu \mathrm{M}$ of minocycline; panels $\mathrm{C}$, D and E, respectively). On the other hand, minocycline at all doses did not reduce the number of TUNEL positive astrocytes (OGD-exposed astrocytes treated with $0, \mathrm{I}$ and $\mathrm{I} 00 \mu \mathrm{M}$ of minocycline; panels $\mathrm{F}, \mathrm{G}$ and $\mathrm{H}$, respectively). Data are shown as mean values $\pm \mathrm{SEM}\left({ }^{*} \mathrm{P}<0.05\right.$. A, I: neurons, B, J: astrocytes). Scale bar: $50 \mu \mathrm{m}$. 

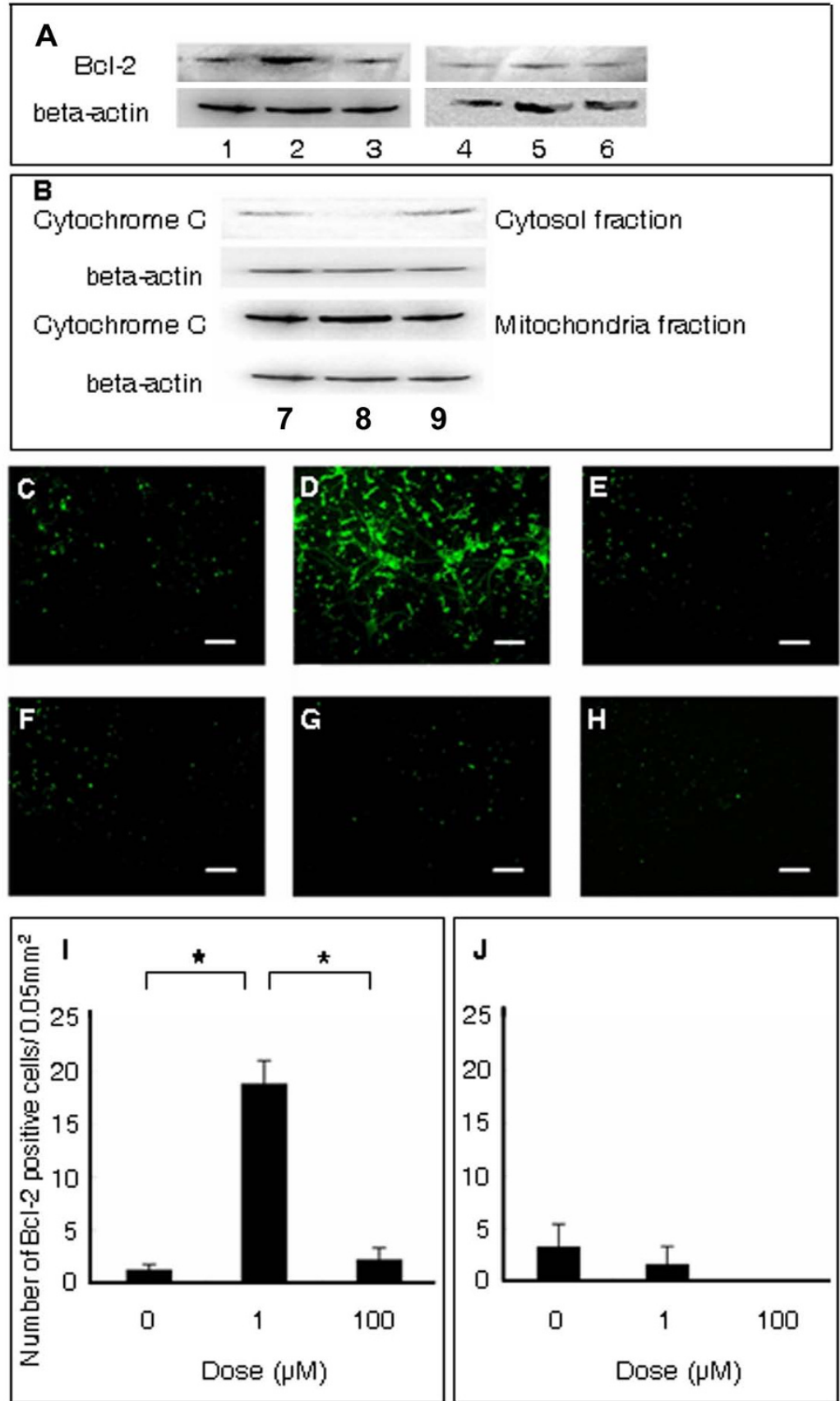

Figure 3

$\mathrm{Bcl}-2$ expression and cytochrome $\mathrm{c}$ release in cultured neurons and astrocytes. Western blotting revealed that low dose minocycline upregulated $\mathrm{Bcl}-2$ expression of neurons ( $\mathrm{A}$ : lysates from $0, \mathrm{I}$ and $\mathrm{I} 00 \mu \mathrm{M}$ of minocycline-treated neurons correspond to lanes I, 2, and 3, respectively) with subsequent inhibition cytochrome c release from mitochondria to cytosol (B: lysates from $0, I$ and $100 \mu \mathrm{M}$ of minocycline-treated neurons correspond to lanes 7,8 , and 9 , respectively). In contrast, minocycline at all doses did not upregulate $\mathrm{Bcl}-2$ expression in astrocytes (A: lysates from $0, \mathrm{I}$ and $\mathrm{I} 00 \mu \mathrm{M}$ of minocyclinetreated astrocytes correspond to lanes 4, 5, and 6, respectively). Immunocytochemical analysis revealed that minocycline low dose (D: I $\mu \mathrm{M})$ significantly increased the number of $\mathrm{Bcl}-2$ positive neurons compared to vehicle-treated (C: $0 \mu \mathrm{M})$ or high dose-treated neurons $(\mathrm{E}: 100 \mu \mathrm{M})$. In contrast, minocycline at all doses did not alter the number of Bcl-2 positive astrocytes (F: $0 \mu \mathrm{M}, \mathrm{G}: \mathrm{I} \mu \mathrm{M}$ and $\mathrm{H}: \mathrm{I} 00 \mu \mathrm{M})$. Quantitative analyses of $\mathrm{Bcl}-2$ positive cells are shown in panels I and J. Data represent mean values \pm SEM (* $p<0.05$. I: neurons, J: astrocytes). Scale bar: $25 \mu \mathrm{m}$. 


\section{Minocycline ameliorates stroke-induced behavioral deficits}

At three days post-stroke, the typical motor and neurological dysfunctions produced by MCAo were significantly blocked by minocycline when intravenously administrated at a low dose $(20 \mathrm{mg} / \mathrm{kg})$ starting at 60 minutes after reperfusion, as revealed by EBST $(0 \mathrm{mg} / \mathrm{kg}: 88 \pm$ $12.5 \%, 20 \mathrm{mg} / \mathrm{kg}: 68.3 \pm 15 \%)\left(\mathrm{F}_{2,27}=10.439 ; \mathrm{p}=\right.$ 0.0004 ) (Figure 4A) and Bederson test ( $0 \mathrm{mg}$ : $1.67 \pm 0.14$, $20 \mathrm{mg} / \mathrm{kg}: 1.16 \pm 0.36$ ) (Kruskal-Wallis $\mathrm{H}$ value $=19.2, \mathrm{df}$ $=2, \mathrm{p}<0.0001$ ) (Figure 4B). In contrast, MCAo stroke animals treated with high dose minocycline $(100 \mathrm{mg} / \mathrm{kg})$ displayed neurological deficits (Bederson: $2.15 \pm 0.38$ ) that were significantly worse and their motor deficits were slightly exacerbated (EBST: $89 \pm 13 \%$; though not significant difference) compared to stroke animals that received vehicle alone. In addition, these stroke animals treated with high dose minocycline performed significantly worse in both behavioral tests than those that received the low dose minocycline ( $\mathrm{p}$ 's $<0.05)$.

\section{Minocycline reduces cerebral infarcts}

Following behavioral testing at three days post-stroke, TTC staining revealed that the infarct volume was significantly reduced by low dose minocycline $(80.1 \pm 41.7$ $\mathrm{mm}^{3}$ ) relative to vehicle-treated stroke group (138.5 \pm $\left.48.8 \mathrm{~mm}^{3}\right)\left(\mathrm{F}_{2,27}=9.552 ; \mathrm{p}=0.0007\right)$ (Figure $\left.5 \mathrm{~A}, \mathrm{~B}, \mathrm{D}\right)$. In particular, the stroke damage within the striatum was significantly smaller in low dose minocycline-treated stroke animals than vehicle-treated stroke animals. In contrast, the infarct volume in high dose minocycline- treated stroke group was significantly larger than those of vehicle-treated stroke group $\left(180.47 \pm 56.1 \mathrm{~mm}^{3}\right)$ (Figure $5 \mathrm{~A}, \mathrm{C}, \mathrm{D})$. Indeed, in some high dose minocycline-treated stroke animals, cerebral infarcts were observed even in the hemisphere contralateral to the MCAo side. Posthoc analyses of hemorrhage revealed $20 \%$ incidence with an average size of $12 \mathrm{~mm}^{2}$, which did significantly differ across treatment groups. Similarly, measurements of edema found no significant differences across groups (although there was a slight reduction in the low dose minocycline group compared to vehicle group), indicating that our analysis of neuronal cell loss (see below) was not affected by edema formation.

\section{Minocycline abrogates MCAo-mediated apoptotic cell death}

A new set of animals ( $n=18$ ) underwent MCAo, randomly assigned to similar minocycline treatment as described above, and euthanized at three days post-stroke for immunohistochemical analyses of apoptotic cell death. Results revealed that $\mathrm{Bcl}-2$ immunoreactivity was significantly increased in the brains of stroke animals that were treated with low dose minocycline, especially within the striatum ipsilateral to the occluded MCA $(20 \mathrm{mg} / \mathrm{kg}$ : $9.83 \pm 1.50$ density/ $0.05 \mathrm{~mm}^{2}$ ) relative to vehicle-treated stroke animals $\left(0.235 \pm 0.112\right.$ cells $\left./ 0.05 \mathrm{~mm}^{2}\right)\left(\mathrm{F}_{2,15}=\right.$ 37.151; $\mathrm{p}<0.0001$ ) (Figure 6A, B, D). In contrast, Bcl-2 immunoreactivity in the same striatal area of high dose minocycline-treated stroke animals was not significantly differrent from vehicle-treated stroke animals $(100 \mathrm{mg} / \mathrm{kg}$ : $1.14 \pm 0.22$ density/0.05 $\mathrm{mm}^{2}$ ) (Figure 6A, C, D). To clar-
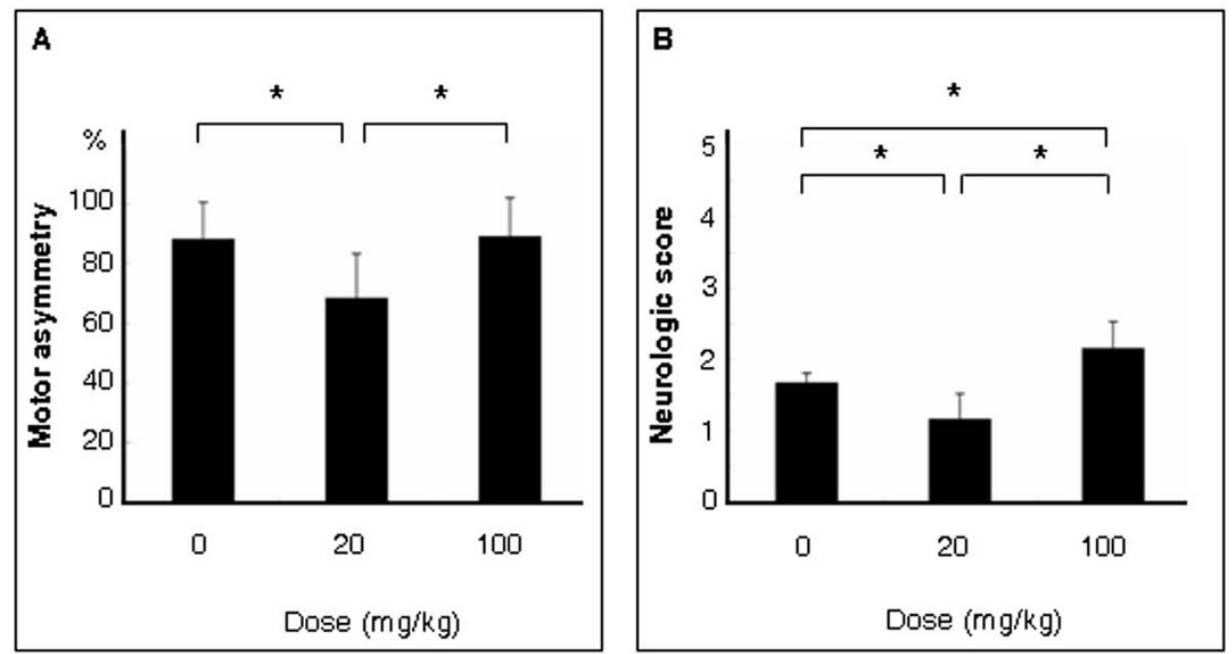

\section{Figure 4}

Motor and neurological performance of stroke rats. Both motor and neurological dysfunctions were significantly ameliorated by low dose minocycline $(20 \mathrm{mg} / \mathrm{kg}$, i.v.), as revealed by elevated body swing test (EBST; A) and Bederson test (B). In contrast, high dose minocycline (100 mg/kg, i.v.) significantly exacerbated neurological deficits and slightly worsened motor deficits. Data are shown as the mean values \pm SEM $(* p<0.05)$. 

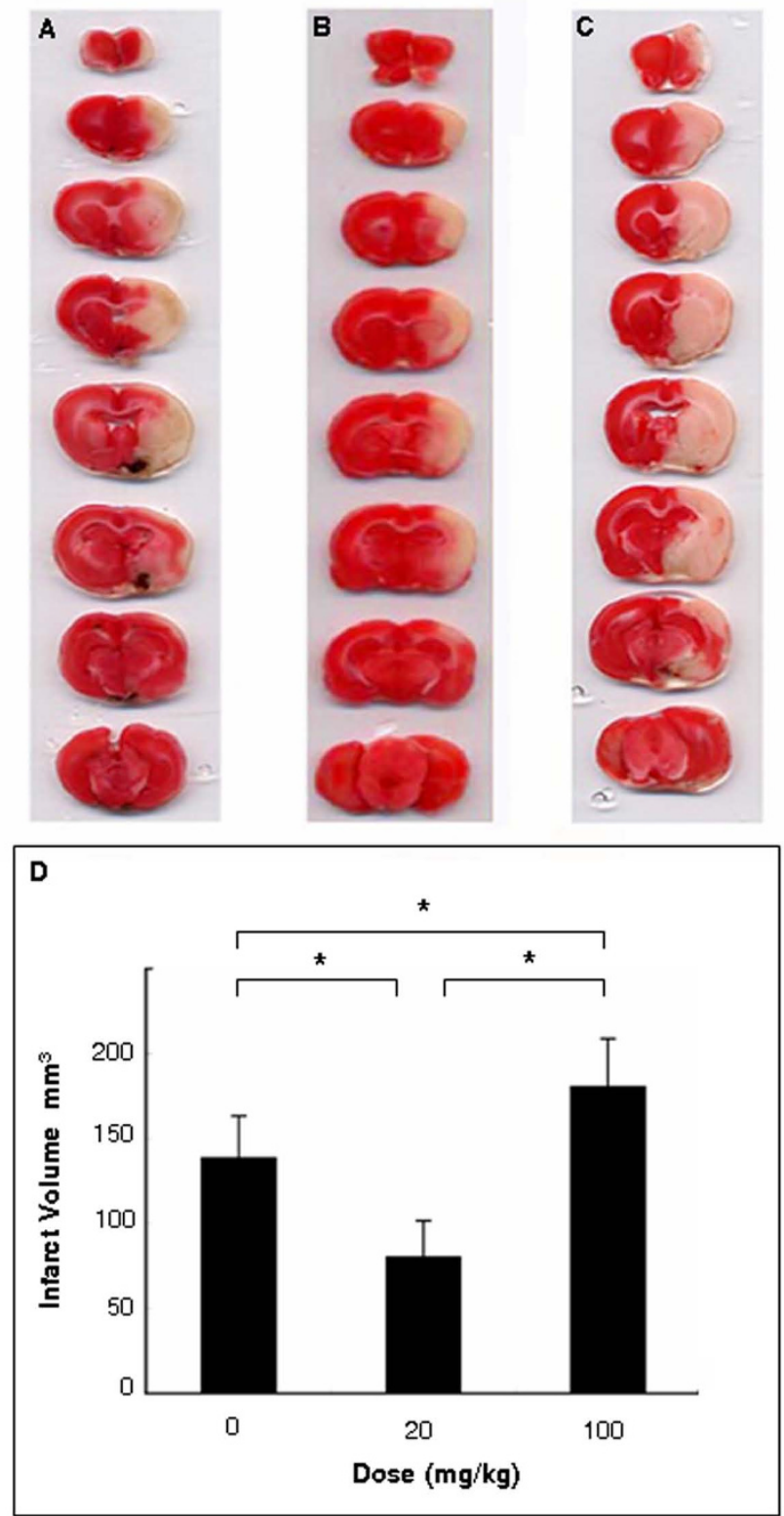

\section{Figure 5}

Cerebral infarct analysis of stroke brains. TTC staining revealed that low dose minocycline $(20 \mathrm{mg} / \mathrm{kg}$; B) significantly reduced cerebral infarct volumes compared to the vehicle group (A). In particular, the striatal infarct volumes in the low dose group were significantly smaller than the vehicle group. In contrast, high dose minocycline ( $100 \mathrm{mg} / \mathrm{kg}$; C) significantly increased the infarct volumes compared to those in the vehicle group. Quantitative analyses are shown in panel D. Data represent mean values \pm SEM $\left(*_{p}<0.05\right)$.

ify which cell type expresses Bcl-2, we examined doublelabeling of $\mathrm{Bcl}-2$ with MAP2 or GFAP by immunohistochemistry in ischemic striatal peri-infact area of each group. Bcl-2 was found co-localized with MAP2 in all groups (Figure 6F-H). In contrast, GFAP positive astro- cytes did not express Bcl-2 (Figure 6I-K). These results suggest that low dose minocycline can exert anti-apoptotic effects via Bcl-2 upregulation in ischemic neurons. A few cells in vehicle-treated stroke rats also expressed Bcl-2 and MAP2 double-labeling, indicating that ischemia alone, without any treatment intervention, might slightly induce the expression of $\mathrm{Bcl}-2$ in neurons.

In addition, whereas TUNEL-positive cells with agglutinated nuclei highly populated the striatal peri-infarct area of high dose minocycline treated or vehicle treated animals, there were significantly fewer TUNEL-positive cells in animals treated with low dose minocycline $\left(\mathrm{F}_{2,15}=\right.$ $35.411 ; \mathrm{p}<0.0001$ ) (Figure 7A-D). Similar dose dependent anti-apoptotic effects were obtained from Bcl-2 immunohistochemistry, in that low dose minocycline significantly increased the number of $\mathrm{Bcl}-2$ positive cells within the striatal peri-infarct area compared to high dose minocycline or vehicle treatment.

\section{Minocycline rescues neurons in the peri-infarct area}

To determine the effect of minocycline on neurons in vivo, we examined the number of Nissl positive cells in ischemic peri-infarct area on consecutive brain sections. Vehicle-treated MCAo stroke rats exhibited neuronal cell loss in the peri-infarct area $\left(152.0 \pm 10.0\right.$ cells $\left./ 0.05 \mathrm{~mm}^{2}\right)$ relative to intact brain $\left(303.3 \pm 13.9\right.$ cells $\left./ 0.05 \mathrm{~mm}^{2}\right)$ (Figure $8 \mathrm{~A}, \mathrm{~B}, \mathrm{E})$. Low dose minocycline $(228.3 \pm 6.9$ cells/ $0.05 \mathrm{~mm}^{2}$ ) revealed significant protective effect relative to vehicle treated group $\left(152.0 \pm 10.1\right.$ cells $\left./ 0.05 \mathrm{~mm}^{2}\right)\left(\mathrm{F}_{3,16}\right.$ $=4$ 9.488; $\mathrm{p}<0.0001$ ) (Figure $8 \mathrm{~B}, \mathrm{C}, \mathrm{E})$, as well as retained fundamental structure of striatum. In contrast, high dose minocycline $\left(104.3 \pm 6.8\right.$ cells $\left./ 0.05 \mathrm{~mm}^{2}\right)$ revealed significant neuronal cell loss $\left(104.3 \pm 16.4\right.$ cells $\left./ 0.05 \mathrm{~mm}^{2}\right)$ relative to vehicle treated group (though no significant difference), in addition to dissolution of fundamental structure of striatum with severe edema (Figure 8B, D, E).

\section{Discussion}

The present study demonstrates that minocycline exerted direct protection on neurons, in the absence of astrocyte participation, against ischemic stroke. An equally important finding is that minocycline not only promoted dosedependent neuroprotective effects, but also induced toxicity at a high dose for both neurons and astrocytes. Both sets of in vitro and in vivo studies corroborated such neuroprotection and toxicity profile of minocycline. In addition, in vitro mechanistic studies revealed that a major therapeutic pathway, by which minocycline prevented the ischemic cell death, is via an anti-apoptotic mechanism. Parallel in vivo data showed that low dose, but not high dose, minocycline attenuated stroke-induced behavioral deficits, decreased apoptotic cell death and reduced cerebral infarction. The intravenous route and the post-stroke delivery further advance the utility of minocycline in the clinic. 

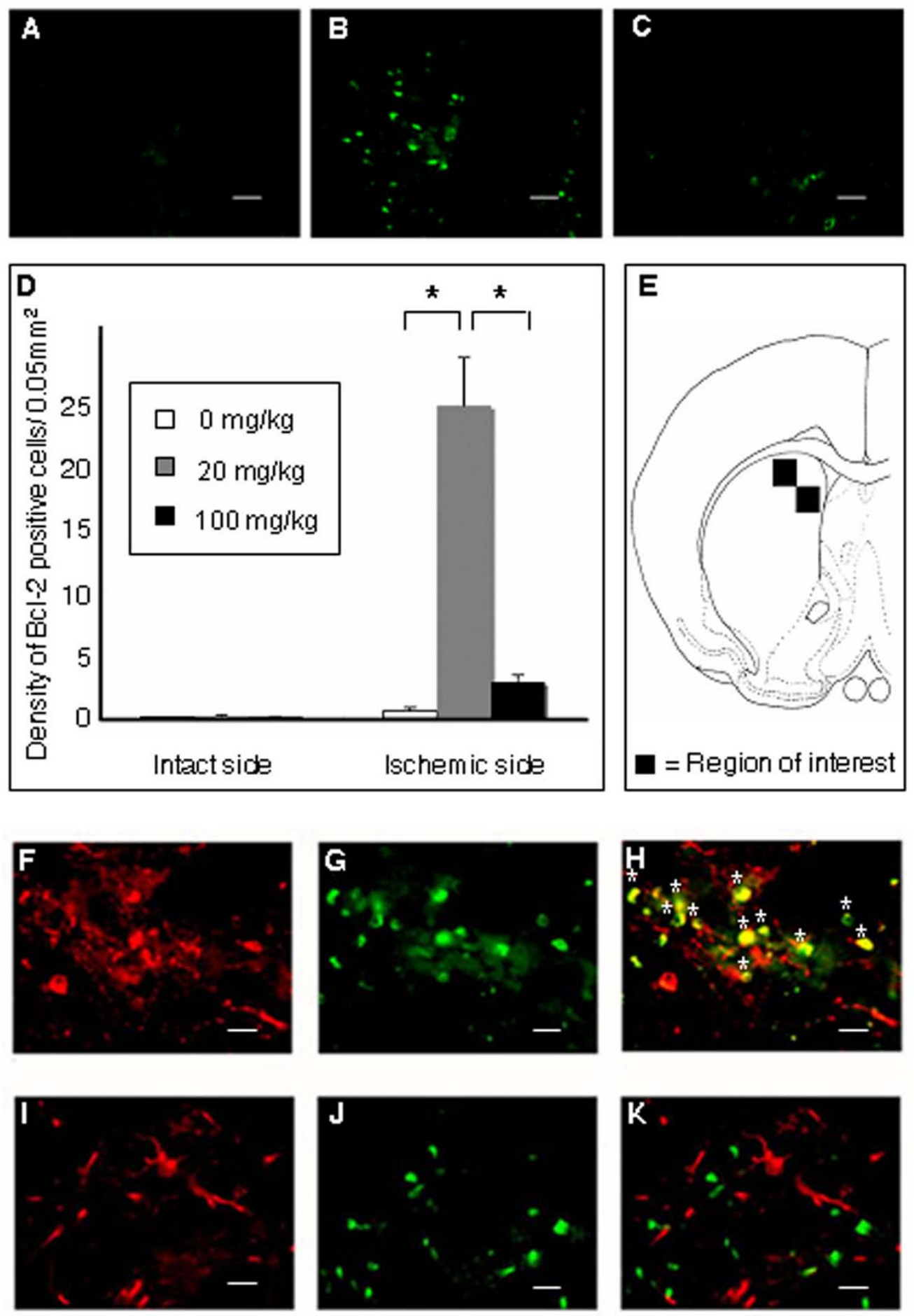

\section{Figure 6}

Tunel staining in the ischemic peri-infarct area. Low dose significantly decreased (B), whereas high dose significantly increased $(C)$ the number of TUNEL positive cells in the ischemic striatal peri-infarct area of minocycline-treated stroke rats compared to the vehicle-treated stroke rats $(A)$. Quantitative analyses of Bcl-2 positive cells are shown in panel D. Data are shown as mean values \pm SEM $\left(*_{p}<0.05\right)$. Four representative ischemic striatal peri-infarct areas $(+0.2 \mathrm{~mm}$ anterior to the bregma), in which TUNEL positive cells were counted (data in panel D), are shown in panel E (square boxes labeled I-4 correspond to areas I-4 in panel D). Scale bar: $25 \mu \mathrm{m}$. 

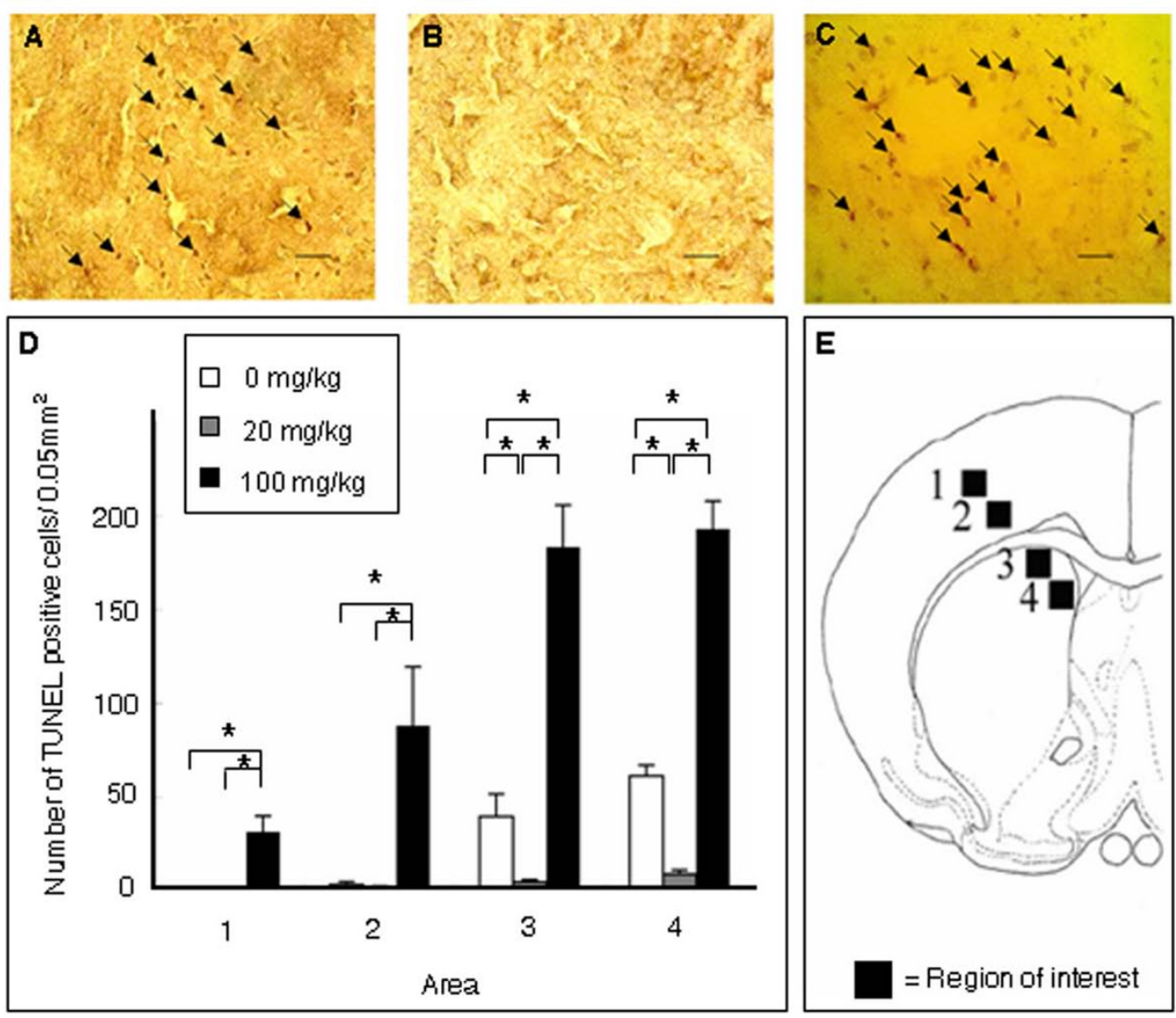

\section{Figure 7}

Bcl-2 expression in the ischemic peri-infarct area. Low dose (B) significantly upregulated, whereas high dose (C) significantly suppressed the $\mathrm{Bcl}-2$ expression in the ischemic peri-infarct area of minocycline-treated rats compared to that in the vehicle-treated rats $(\mathrm{A})$. Quantitative analyses of $\mathrm{Bcl}-2$ positive cells are shown in panel $\mathrm{D}$. Data are shown as mean values \pm SEM (*p < 0.05). Two representative ischemic striatal peri-infarct areas $(+0.2 \mathrm{~mm}$ anterior to the bregma), in which Bcl-2 positive cells were counted (data in panel D), are shown in panel E (square boxes). Co-localization of Bcl-2 and MAP2 was found in ischemic striatal peri-infarct area, suggesting anti-apoptotic effects of minocycline via Bcl-2 upregulation in ischemic neurons (F-H). In contrast, GFAP positive astrocytes did not express Bcl-2 (I-K). Scale bar: $25 \mu \mathrm{m}(\mathrm{A}-\mathrm{C}), \mathrm{I} 2.5 \mu \mathrm{m}(\mathrm{F}-\mathrm{K})$; asterisks (*): merged cell; green and red immunofluorescent markers correspond to $\mathrm{Bcl}-2$ and MAP2, respectively.

To date, the primary CNS mechanism implicated in minocycline neuroprotection is the drug's highly potent inhibitory effect on microglial activation, which is achieved by blocking the phosphorylation of p38 and the translocation of 5-Lipoxygenase into the nucleus, thereby preventing the release of cytokines and the induction of inflammation $[15,40,43-45]$. On the other hand, recent evidence has shown that minocycline in the periphery affords protective effects on kidney cells against ischemia via the apoptotic Bcl-2/cytochrome c pathway [29]. We report here that minocycline also promoted protection against ischemia in the CNS by arresting apoptotic Bcl-2/ cytochrome c pathway. In our in vitro OGD condition, cultured neurons and astrocytes underwent apoptosis-like cell death as revealed by induction of caspase $3 / 7$ activity and DNA fragmentation (TUNEL positive cells). Treatment with low, but not high dose minocycline abrogated apoptosis characterized by reduced caspase 3/7 activity and decreased number of TUNEL positive cells. Of note, such blockade of OGD-induced apoptosis by low dose minocycline only occurred in cultured neurons and was not evident in cultured astrocytes.

In stroke brains, increased chemokine mRNA expression displays a biphasic profile, being found initially in neurons, then subsequently in astrocytes [46]. Of interest, high levels of chemokines were found in areas of gliosis surrounding recent infarcts [47-49] and correlated with the accumulation of macrophage/microglia in the ischemic lesion, suggesting chemokine's role in the 

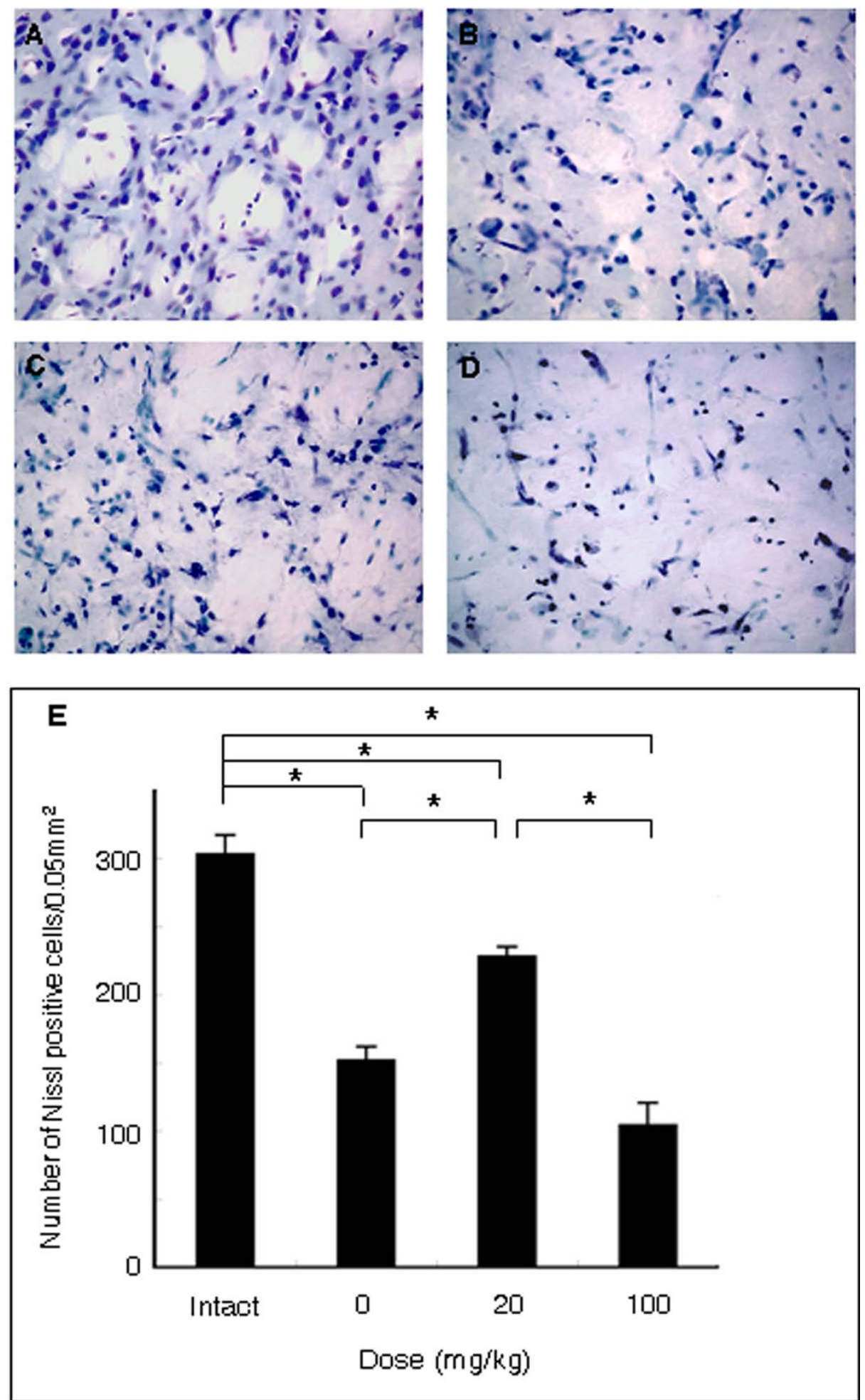

Figure 8

Neuronal survival in the ischemic peri-infarct area. Neuronal survival in the ischemic striatal peri-infarct area, visualized with cresyl violet stain, was significantly preserved by low dose minocycline (A: intact control, B: vehicle, C: $20 \mathrm{mg} / \mathrm{kg}, \mathrm{D}: 100$ $\mathrm{mg} / \mathrm{kg}$ ). In contrast, high dose minocycline resulted in the collapse of fundamental neuroarchitecture of the striatum accompanied by severe edema. Data are shown as mean values \pm SEM $(* p<0.05)$. Scale bar: $25 \mu \mathrm{m}$. 
recruitment of inflammatory cells into the brain in response to stroke [49-52]. Based on the above observations, suppressing chemokine elevation during its initial onset in neurons, before astrocytes become involved in this inflammation-ischemia-triggered secondary cell death, may provide better therapeutic outcome than treatment regimen targeting astrocytes. Although in recent years enhancing astrocyte survival has been suggested as an alternative protective approach against ischemic damage $[53,54]$, therapeutic strategies that confer direct neuronal protection are likely to improve clinical prognosis. The present results indicate that minocycline, in addition to its established anti-microglial activity, could directly protect neurons via an anti-apoptotic mechanism.

To further clarify the anti-apoptotic features of minocycline, we examined the alterations in expression of apoptosis-related components, specifically the cell survivalenhancing $\mathrm{Bcl}-2 /$ cytochrome $\mathrm{c}$ pathway. Our results revealed that low dose minocycline protected again neurons, but not astrocytes against OGD by elevating $\mathrm{Bcl}-2$ expression and consequently strengthening the anchor of cytochrome $\mathrm{c}$ to the mitochondria. We extend here the participation of Bcl-2/cytochrome c pathway in minocycline's direct protection of OGD-exposed neurons, previously shown in ischemic kidney cells [29].

To reveal the possible toxic side effects of minocycline, we similarly examined cell survival and apoptosis in OGDexposed cultured neurons and astrocytes treated with high dose $(100 \mu \mathrm{M})$ minocycline. Minocycline at a high dose was toxic as revealed by markedly reduced cell survival of both OGD-exposed neurons and astrocytes compared to vehicle treated OGD-exposed cells. Moreover, relative to vehicle treated OGD exposed cells, high dose minocycline did not elevate Bcl-2 expression, but increased caspase 3/ 7 activity, as well as the number of TUNEL positive cells in the ischemic striatum.

In parallel to the toxicity profile of minocycline observed in the in vitro OGD condition, high dose minocycline exacerbated both behavioral and histological deficits in stroke animals. In contrast, low dose minocycline increased Bcl-2, but decreased TUNEL positive cells in the ischemic peri-infarct area. Moreover, low dose minocycline-treated animals exhibited a pattern of Bcl-2 expression that was only found in neurons, but not in astrocytes, further supporting the neuroprotective mechanism whereby minocycline exerted anti-apoptotic effects directly on neurons.

In previous reports, therapeutic efficacy in different animal models of neurological disorders was consistently observed when minocycline was administered $3 \mathrm{mg} / \mathrm{kg}$ $45 \mathrm{mg} / \mathrm{kg}$ either intravenously or intraperitoneally [3739]. Recent studies have suggested that depending on the animal species (i.e., mice), minocycline may confer neurotoxicity in experimental ischemia $[19,38,42]$ and Parkinson's disease [41]. These reports and the present data, taken together, further clarified the toxicity profile of minocycline highlighting critical factors including type of cell line (for in vitro studies), experimental injury paradigm, and dosage, as well as delivery route of minocycline [19,37-39].

The observed dose-dependent protection of neurons over astrocytes by low dose minocycline, and the neurotoxic effects of high dose minocycline provide guidance in designing the clinical protocol for stroke patients. Because astrocytes play a crucial role in blood brain barrier maintenance, a perturbed astrocyte viability, as seen with high dose minocycline, may compromise the barrier that could allow inflammatory cells to penetrate the CNS and exacerbate the stroke deficits. Indeed, most of the animals that received high dose minocycline exhibited severe edema. The establishment of an effective dose range that confers protection on neurons, while not disrupting astrocytes, would perhaps lead to improved therapeutic outcome of minocycline.

Minocycline's inability to protect astrocytes or to increase Bcl-2 expression in these cells in vitro seems to be the most original finding of this study. Our approach to use low doses and high doses to show minocycline's protection versus toxicity in the same in vitro and in vivo stroke models is clinically relevant since the drug is already in clinical trials. At first glance, the choice for the present high doses of minocycline (100 $\mu \mathrm{M}$ or $100 \mathrm{mg} / \mathrm{kg})$ would seem extremely high, considering that in a clinical trial [21] multiple sclerosis patients who received orally $200 \mathrm{mg}$ minocycline daily dose (equals $2.85 \mathrm{mg} / \mathrm{kg}$ for $70 \mathrm{~kg}$ person, serum levels reach maximum of $4 \mathrm{mg} / \mathrm{l}=8 \mathrm{uM}$ ) during a 6-month period exhibited no observable significant side effects. However, our recent study clearly demonstrates that a $3 \mathrm{mg} / \mathrm{kg}$ intravenous dose of minocycline is required to obtain serum levels in rats similar to that achieved in humans after a standard $200 \mathrm{mg}$ dose [37], suggesting differences in the drug metabolism between rats and humans. Accordingly, the rationale for selecting the present doses of minocycline is based on our studies $[37,39]$ and those of others $[13,28,34,55,56]$ indicating that these doses correspond to the clinically relevant doses of minocycline in stroke rodent models. In addition, we extended the high dose range to reveal the toxicity profile of minocycline. Indeed, a multiple high dose minocycline injection regimen, involving subcutaneous $135 \mathrm{mg} / \mathrm{kg}$ over 2 days followed by $68 \mathrm{mg} / \mathrm{kg}$ over the succeeding two days, was recently shown to exacerbate the striatal damage produced by hypoxic-ischemic injury in rats [42]. Depending on the dose and route of delivery, discordant results and conclusions accompany the actions of minocycline in various stroke and neurodegeneration models. 
The present data underscore that the minocycline dose is critical as it might attenuate or worsen the stroke outcome. While many studies have pursued intraperitoneal or subcutaneous injections of high dose minocycline in order to promote neuroprotection, we show here that robust neuroprotective effects in acute stroke can be achieved with intravenous low dose minocycline, thereby circumventing the toxicity now increasingly being recognized with high dose minocycline. This neuroprotective action of low dose minocycline at a clinically suitable dosing regimen advances the entry of this drug for phase I human stroke trials. In view of a recent clinical trial showing that the relatively high dose of $400 \mathrm{mg} /$ day for 9 months minocycline led to an accelerated deterioration in the amyotrophic lateral sclerosis functional rating scale, accompanied by gastrointestinal and neurological adverse events [57], a more careful consideration of minocycline dose is indicated as similarly shown in the present study.

\section{Conclusion}

In conclusion, the safety and therapeutic efficacy of low dose minocycline and its robust neuroprotective effects during acute ischemic stroke make it an appealing drug candidate for stroke therapy. The implication of the present direct minocycline protection of neurons, as opposed to the reported inhibition of microglial activity, can be best appreciated by the fact that stroke triggers abrupt neuronal cell death that would require immediate intervention to rescue ischemic cells. A delay in abrogating the primary stroke-induced cell death could result in "fixed" or devastating histological and functional deficits that will be difficult to repair. Coupled with the ability of minocycline to block the microglial activation occurring at later post-stroke periods, we now provide evidence that minocycline is also able to achieve an expedited direct neuroprotection against ischemia at early time points. To our knowledge, such two-pronged neuroprotective approach targeting both primary and secondary cell death processes associated with stroke has not been shown with monotherapy. Minocycline stands as a multiple site of action therapeutic drug, which clinically should be effective in treating neurological diseases, like stroke, characterized by many facets of cell death cascades.

\section{Methods}

The present experimental research and relevant ethical issues were approved by Veterans Affair Medical Center Institutional Animal Care and Use Committee, and adhered to National Institutes of Health guidelines.

\section{In vitro study \\ Cell culture}

Primary cultures of neurons and astrocytes were derived from the rat (Sprague-Dawley) striatum and maintained in culture following the supplier's protocol (CAMBREX, $\mathrm{MD})$. Briefly, immediately after thawing, cells $\left(4 \times 10^{4}\right.$ cells/well) were seeded and grown in 96-well plate coated by poly-l lysine in Neurobasal media (GIBCO, CA) containing $2 \mathrm{mM}$ L-glutamine, 2\% B27 (GIBCO, CA) and 50 $\mathrm{U} / \mathrm{ml}$ penicillin and streptomycin for $7-10$ days at $37^{\circ} \mathrm{C}$ in humidified atmosphere containing $5 \% \mathrm{CO}_{2}$. Purity of the cells were immunocytochemically determined to be > $99 \%$ for both neuronal and astrocytic cell population as revealed by DARPP-32 and GFAP immunostaining, respectively. Moreover, we confirmed that these cells were appropriate for the oxygen glucose deprivation (OGD) injury model, where glutamate excitotoxicity plays an important role, as revealed by expression of glutamate receptors (determined immunocytochemically using vesicular glutamate transpoter-1) in 50\% of the neuronal and astrocytic cell population.

\section{Oxygen-glucose deprivation (OGD)}

Cultured cells were exposed to the OGD injury model as described previously [58] with few modifications. Briefly, culture medium was replaced by a glucose-free Earle's balanced salt solution (BSS) with the following composition $\left(116 \mathrm{mM} \mathrm{NaCl}, 5.4 \mathrm{mM} \mathrm{KCl}, 0.8 \mathrm{mM} \mathrm{MgSO}_{4}, 1 \mathrm{mM}\right.$ $\mathrm{NaH}_{2} \mathrm{PO}_{4}, 26.2 \mathrm{mM} \mathrm{NaHCO}, 0.01 \mathrm{mM}$ glycine, $1.8 \mathrm{mM}$ $\mathrm{CaCl}_{2}$, and $\mathrm{pH}$ adjusted to 7.4 with or without minocycline. Cultured cells were placed in humidified chamber, then equilibrated with continuous flow of $92 \% \mathrm{~N}_{2}$ and $8 \% \mathrm{O}_{2}$ gas for 15 minutes. After this equilibrium, the chamber was sealed and placed into the incubator at $37^{\circ} \mathrm{C}$ for 75 minutes, 2 hours, 4 hours and 12 hours for Western blot, caspase assay, MTT assay and Trypan blue stain, respectively. For Western blot, cells were subsequently exposed to standard medium in $5 \% \mathrm{CO}_{2}$ incubator for an additional 6 hours to generate apoptosis-related proteins [58].

\section{Cell viability}

Cell viability was evaluated by ATP activity following the supplier's protocol (Promega, WI) and by Trypan blue (Sigma, MO). Briefly, MTT assay was carried out by adding MTT assay solution immediately after OGD. The intensities of chemiluminescence of ATP activity were measured and calculated by Image station 2000R system (Kodak, NY). In addition, Trypan blue exclusion method was conducted and mean viable cell counts were calculated in three randomly selected areas $\left(0.2 \mathrm{~mm}^{2}\right)$ in each well $(\mathrm{n}=$ 5 per treatment condition) to reveal the cell viability for each treatment condition.

\section{Caspase 3/7 assay}

For caspase assay, the same number of cells $(40,000$ cells/ well) was seeded in 96-well plate and maintained as described above. After OGD treatment for 2 hours, caspase 3/7 assay was examined following the manufacturer's protocol (Promega, WI). Briefly, examination of caspase activity was performed by adding caspase assay solution immediately after OGD. Following incubation at 
room temperature, the intensities of chemiluminescence were measured and calculated following the procedures mentioned above. The intensities were compared between minocycline-treated and vehicle-treated OGD groups after subtracting the mean of no OGD control group.

\section{Immunoblotting}

For Western blot of Bcl-2, cultured cells were extracted and homogenized by solution containing $20 \mathrm{mM}$ Tris- $\mathrm{HCl}$ (7.6), $150 \mathrm{mM} \mathrm{NaCl}, 1 \% \mathrm{NP} 40,1 \mathrm{mM}$ PMSF, $1 \mu \mathrm{g} / \mathrm{ml} \mathrm{leu-}$ peptin, $1 \mu \mathrm{g} / \mathrm{ml}$ TPCK and $1 \mu \mathrm{g} / \mathrm{ml}$ TLCK. For cytochrome c assay, cultured cells were extracted following the manufacturer's protocol (BioVision, CA). Briefly, cells were homogenized in ice-cold buffer containing protease inhibitors. After centrifugation at $700 \mathrm{~g}$ for 10 minutes at $4{ }^{\circ} \mathrm{C}$, the supernatant was further centrifuged at $12,000 \mathrm{~g}$ for 40 minutes at $4^{\circ} \mathrm{C}$. Thereafter, the supernatant was collected as cytosol fraction, and the pellet was resuspended with mitochondria extraction buffer containing DTT and protease inhibitor, and stored as mitochondria fraction. Collected samples $(50 \mu \mathrm{g})$ were loaded into $12.5 \%$ SDS-PAGE electrophoresis and transferred to a nitrocellulose membrane. After blocking by 3\% skim milk in $10 \mathrm{mM}$ Tris-HCl (pH 7.6), $150 \mathrm{mM} \mathrm{NaCl}$ and $0.3 \%$ TritonX at room temperature for one hour, the blot was probed with a monoclonal antibody against $\mathrm{Bcl}-2$ (1:2000, Chemicon, CA), and cytochrome c (1:500, Pharmigen, CA), and visualized using a HRP-conjugated antimouse IgG antibody and chemiluminescence system (Amersham, UK).

\section{Immunocytochemistry}

Each $1 \times 10^{5}$ cells were plated on 8 well Permanox ${ }^{\circledR}$ slides (Nalge Nunc Int, IL) at two days before fixation. Cultured cells were treated with 4\% paraformaldehyde (PFA) for 10 minutes at room temperature after rinsing with phosphate buffered saline (PBS). After blocking reaction with 10\% normal goat serum (Vector, CA), cells were incubated overnight at $4^{\circ} \mathrm{C}$ with an anti-Bcl-2 monoclonal antibody (1:100, Chemicon, CA), or anti-MAP2 polyclonal antibody (1:1000, Chemicon) with 10\% normal goat serum. After several rinses in PBS, cells were incubated for 45 minutes at room temperature in FITC-conjugated antimouse IgG (1:1000, Molecular probe, CA), or Rhodamine-conjugated anti-rabbit IgG (1:2000, Molecular probe, CA) for visualization. Cells were processed for DAPI. immunostaining then subsequently embedded with mounting medium. Immunofluorescent images were visualized using Zeiss Axiophot 2 and the number of immunopositive cells was counted per high power field view selected at random $\left(50,000 \mu \mathrm{m}^{2}\right)$. In addition, control studies included exclusion of primary antibody and substituted with $10 \%$ normal goat serum in PBS. No immunoreactivity was observed in these controls. All studies were conducted in quadruplicates, with $n=100$ per treat- ment condition. Assessments were performed blindly by an independent investigator.

\section{TUNEL staining}

Cultured cells were washed with PBS. As described in our previous report [59], the TUNEL staining was carried out with DNA fragmentation detection kit (Roche, Mannheim, Germany), which detects double-strand breaks in genomic DNA with diaminobenzidine. The number of TUNEL positive cells was counted per high power field view selected at random $\left(200,000 \mu \mathrm{m}^{2}\right)$ via Zeiss Axiophot 2.

\section{In vivo study}

\section{Stroke surgery}

Sprague-Dawley, male 10-week old rats, weighing about $250 \mathrm{~g}$, were anesthetized with gas inhalation composed of $30 \%$ oxygen $(0.3 \mathrm{~L} / \mathrm{min})$ and $70 \%$ nitrous oxide $(0.7 \mathrm{~L} /$ min) mixture. The gas was passed through an isoflurane vaporizer set to deliver 3\% to $4 \%$ isoflurane during initial induction and $1.5 \%$ to $2 \%$ during surgery. Transient unilateral focal ischemia was produced using a well-established middle cerebral artery occlusion (MCAo) using the intraluminal suture model as previously described $[53,60]$. Physiological parameters, via blood gas assays (using the tail vein for sampling), and ischemia and reperfusion levels determined by Laser Doppler measurements, did not differ across all MCAo stroke groups. The body temperature of animals was maintained at $37^{\circ} \mathrm{C}$ during the surgery until they recovered from anesthesia. Based on our pilot studies, a 30-minute MCAo produces a welldelineated striatal penumbra with minimal necrotic region. Laser Doppler was used during the 30-minute occlusion period to verify reduction in blood flow, with the probe placed on the dura using rostro-caudal and lateral coordinates $(\mathrm{AP}:+2.0, \mathrm{ML}: \pm 2.0)$ relative to bregma. Insertion of the intraluminal filament led to $80 \%$ or greater reduction in cortical blood flow, which was used as criterion for inclusion of animals to the study and their subsequent random assignment to the treatment groups. TTC staining at 24 hours after MCAo revealed a small striatal infarct core with sparing of much of the striatum and cortex. Ischemic damage progressed beyond this time point and by 72 hours post-stroke the infarct included more striatal tissue and a substantial amount of cortex. The term "peri-infarct" is subsequently used here to refer to the tissue adjacent which became incorporated into the infarct beyond the 24-hour period. The mortality rate for the present MCAo study was 3 animals from original 33 animals, which equate to about $10 \%$; these animals died immediately after stroke surgery. Minocycline doses of 20 $\mathrm{mg} / \mathrm{kg}$ or $100 \mathrm{mg} / \mathrm{kg}$ in $5 \mathrm{ml}$ saline or vehicle were administered intravenously (via the jugular vein) as a single bolus at 60 minutes after the reperfusion. This dosing regimen of minocycline was based on our previous papers $[29,37]$. 


\section{Behavioral tests}

Behavioral estimation was performed by using semi quantitative analysis of motor asymmetry (elevated body swing test, EBST) and neurological function (Bederson test) at 72 hours just prior to euthanasia as previously described [60-62]. The analyses of Bederson data were from raw individual scores generated from a scale of $0-3$, in the order of severity of impairments. To prevent any examiner's bias, all behavioral evaluations were performed by an investigator blinded to the treatment conditions.

\section{Infarct estimation via 2,3,5-triphenyltetrazolium chloride (TTC) staining}

After behavioral testing at 72 hours post stroke, animals were anesthetized with a lethal dose of equithesin (500 $\mathrm{mg} / \mathrm{kg}$, i.p.), decapitated and the brains harvested. Histological determination of infarct volume was performed using standard TTC staining, and quantitative image analysis was carried out as previously described [63-65]. Infarct volume $\left(\mathrm{mm}^{3}\right)$ was determined using the following formula $=2 \mathrm{~mm}$ (thickness of the section) $\times[$ sum of the infarction area in all brain section $\left.\left(\mathrm{mm}^{3}\right)\right]$. To minimize artifacts produced by postischemic edema in the infarcted area, the infarction area in the ipsilateral hemisphere was indirectly measured by subtracting the noninfarcted area in the ipsilateral hemisphere from the total intact area of the contralateral hemisphere. However, because edema extends beyond the border of the infarct, into peri-infarct tissues, the 72-hour time point of TTC assay might have likely represented maximum edema as brain swelling caused by focal ischemia started to resolve beyond this time point. Because cell densities are based on cell counts within a defined area, the results are likely to have been influenced by edema.

\section{Immunohistochemistry}

Under deep anesthesia, rats were sacrificed at 72 hours after reperfusion, and perfused through the ascending aorta with $200 \mathrm{ml}$ of cold PBS, followed by $100 \mathrm{ml}$ of $4 \%$ PFA in PBS. Brains were removed and post-fixed in the same fixative for 3 days followed by $30 \%$ sucrose in phosphate buffer $(\mathrm{PB})$ for 1 week. Six series of coronal sections were cut at a thickness of $30 \mu \mathrm{m}$ by cryostat and stored at $-20^{\circ} \mathrm{C}$. Free floating sections for immunohistochemistry were incubated overnight at $4{ }^{\circ} \mathrm{C}$ with an anti-Bcl-2 monoclonal antibody (1:50, Chemicon), anti-MAP2 polyclonal antibody (1:500, Chemicon), or anti-GFAP polyclonal antibody (1:500, Chemicon, CA) with 10\% normal goat serum. After several rinses in PBS, the sections were visualized following the method described above with modification to accelerate FITC with biotin conjugated antimouse IgG antibody and FITC conjugated streptoavidin (1:500, Sigma, MO). Control studies included exclusion of primary antibody substituted with $10 \%$ normal goat serum in PBS. No immunoreactivity was observed in these controls. Furthermore, TUNEL staining was performed as described in in vitro section, using DNA fragmentation detection kit (Roche, Mannheim, Germany). Finally, brain sections were counterstained with cresyl violet stain. Immunofluorescent and light microscopy were carried out using Zeiss Axiophot 2. Sections were blind-coded and Abercrombie's formula [66] was used to calculate the total number of immunopositive cells.

\section{Morphological Analysis}

The density of the Bcl-2 positive cells and TUNEL positive cells in the ischemic peri-infarct area (determined by cresyl violet stain using consecutive sections) was estimated and analyzed as described previously [67]. Briefly, the level of $+0.2 \mathrm{~mm}$ anterior to the bregma based on the atlas of Paxinos and Watson [68] was selected for semi-quantitative analysis. For estimation of TUNEL-positive cells, TUNEL positive cells were counted in four consecutive $0.05 \mathrm{~mm}^{2}$ regions of the outer boundary zone of each medial striatal and cortical infarction. The total number of TUNEL positive cells with agglutinated nuclei in the four areas was counted and expressed as cells $/ \mathrm{mm}^{2}$ for statistical analyses. For estimation of Bcl-2 positive cells, two striatal areas (each area: $0.05 \mathrm{~mm}^{2}$ ) in the ischemic periinfarct area and symmetrical two areas in the contralateral side were analyzed using Scion Image software (Scion Corp., MD). The areas were captured, binary images created with a distinct threshold, then the positive areas calculated and summed up. The ratio of lesion to intact side was used for statistical analyses. Additionally, confocal analysis was performed using a Zeiss LSM 510 confocal Laser scanning microscope.

\section{Statistics}

In order to determine significant differences in cerebral infarcts, motor deficits, the number of TUNEL positive cells and Bcl-2 positive cells were analyzed using Repeated Measures of ANOVA followed by post hoc Scheffe's test. For Bederson neurological deficits, the non-parametric Kruskal-Wallis test was performed. Statistical significance was preset at $\mathrm{p}<0.05$.

\section{Authors' contributions}

NM assisted in study conceptualization, design and coordination, and also carried out the histological and molecular assays and drafted the manuscript. TY performed the behavioral tests and immunohistochemical analyses. $\mathrm{KH}$ assisted in stroke surgeries and histological procedures. LX performed the stroke surgeries and assisted in histological analyses. MM assisted in the molecular assays and analyses. GY assisted in behavioral, surgical and histological assays. YK assisted in molecular analyses. KO participated in data analyses and manuscript write-up. DCH assisted in study design and manuscript write-up. CVB conceived the study, supervised its design and coordination, and led the manuscript write-up. All authors read and approved the final manuscript. 


\section{Acknowledgements}

This project was funded by MCG Department of Neurology Funds. The authors thank the technical assistance of Ms. Eunkyung 'Cate' Bae and Dr. Seong Jin $\mathrm{Yu}$ in the final preparation of the manuscript.

\section{References}

I. Fiskum G, Murphy AN, Beal MF: Mitochondria in neurodegeneration: acute ischemia and chronic neurodegenerative diseases. I Cereb Blood Flow Metab 1999, I 9:35I-369.

2. Zipfel GJ, Lee JM, Choi DW: Reducing calcium overload in the ischemic brain. N Engl J Med I999, 34 I:I543-I544.

3. Paschen W: Role of calcium in neuronal cell injury: which subcellular compartment is involved? Brain Res Bull 2000, 53:409-4I3.

4. Yuan J, Yankner BA: Apoptosis in the nervous system. Nature 2000, 407:802-809.

5. Chan $\mathrm{PH}$ : Reactive oxygen radicals in signaling and damage in the ischemic brain. J Cereb Blood Flow Metab 2001, 2 I:2-14.

6. Horn J, Limburg M: Calcium antagonists for ischemic stroke: a systematic review. Stroke 200I, 32:570-576.

7. Yu SP, Choi DW: Ions, cell volume, and apoptosis. Proc Natl Acad Sci USA 2000, 97:9360-9362.

8. Lo EH, Dalkara T, Moskowitz MA: Mechanisms, challenges and opportunities in stroke. Nat Rev Neurosci 2003, 4:399-4I5.

9. Lebeurrier $N$, Vivien $D$, Ali C: The complexity of tissue-type plasminogen activator: can serine protease inhibitors help in stroke management? Expert Opin Ther Targets 2004, 8:309-320.

10. Clifton GL: Hypothermia and hyperbaric oxygen as treatment modalities for severe head injury. New Horiz I995, 3:474-478.

II. De Georgia MA, Krieger DW, Abou-Chebl A, Devlin TG, Jauss M, Davis SM, Koroshetz W], Rordorf G, Warach S: Cooling for Acute Ischemic Brain Damage (COOL AID): a feasibility trial of endovascular cooling. Neurology 2004, 63:312-317.

12. Zhang JH, Lo T, Mychaskiw G, Colohan A: Mechanisms of hyperbaric oxygen and neuroprotection in stroke. Pathophysiology 2005, 1 2:63-77.

13. Yrjanheikki J, Keinanen R, Pellikka M, Hökfelt T, Koistinaho J: Tetracyclines inhibit microglial activation and are neuroprotective in global brain ischemia. Proc Natl Acad Sci USA 1998, 95: $15769-15774$.

14. Yrjanheikki J, Tikka T, Keinanen R, Goldsteins G, Chan PH, Koistinaho J: A tetracycline derivative, minocycline, reduces inflammation and protects against focal cerebral ischemia with a wide therapeutic window. Proc Natl Acad Sci USA 1999, 96: 13496-13500.

15. Domercq M, Matute C: Neuroprotection by tetracyclines. Trends Pharmacol Sci 2004, 25:609-6I2.

16. Chen M, Ona VO, Li M, Ferrante RJ, Fink KB, Zhu S, Bian J, Guo L, Farrell LA, Hersch SM, Hobbs W, Vonsattel JP, Cha JH, Friedlander RM: Minocycline inhibits caspase-I and caspase-3 expression and delays mortality in a transgenic mouse model of Huntington disease. Nat Med 2000, 6:797-801.

17. Du Y, Ma Z, Lin S, Dodel RC, Gao F, Bales GF, Triarhou LC, Chernet E, Perry KW, Nelson DLG, Luecke S, Phebus LA, Bymaster FP, Paul PM: Minocycline prevents nigrostriatal dopaminergic neurodegeneration in the MPTP model of Parkinson's disease. Proc Natl Acad Sci USA 2001, 98:|4669-|4674.

18. Wells JE, Hurlbert RJ, Fehlings MG, Yong VW: Neuroprotection by minocycline facilitates significant recovery from spinal cord injury in mice. Brain 2003, I 26:1628-1637

19. Diguet E, Gross CE, Tison F, Bezard E: Rise and fall of minocycline in neuroprotection: need to promote publication of negative results. Exp Neuroll 2004, 89:1-4.

20. Hunter CL, Quintero EM, Gilstrap L, Bhat NR, Granholm AC: Minocycline protects basal forebrain cholinergic neurons from mu p75-saporin immunotoxic lesioning. Eur J Neurosci 2002, 19:3305-3316.

21. Metz LM, Zhang Y, Yeung M, Patry DG, Bell RB, Stoian CA, Yong VW, Patten SB, Duquette $P$, Antel JP, Mitchell JR: Minocycline reduces gadolinium-enhancing magnetic resonance imaging lesions in multiple sclerosis. Ann Neurol 2004, 55:756.

22. Yong VW, Wells J, Giuliani F, Casha S, Power C, Metz LM: The promise of minocycline in neurology. Lancet Neurol 2004, 3:744-75I
23. Zemke D, Majid A: The potential of minocycline for neuroprotection in human neurologic disease. Clin Neuropharmacol 2004, 27:293-298.

24. Li WW, Setzu A, Zhao C, Franklin RJM: Minocycline-mediated inhibition of microglia activation impairs oligodendrocyte progenitor cell responses and remyelination in a nonimmune model of demyelination. I Neuroimmunol 2005, I 58:58-66.

25. Tikka TM, Koistinaho JE: Minocycline provides neuroprotection against $\mathbf{N}$-methyl-D-aspartate neurotoxicity by inhibiting microglia. J Immunol 200I, I 66:7527-7533.

26. Tikka T, Fiebich BL, Goldsteins G, Keinänen R, Koistinaho J: Minocycline, a tetracycline derivative, is neuroprotective against excitotoxicity by inhibiting activation and proliferation of microglia. I Neurosci 200 I, 2 I:2580-2588.

27. Lin S, Zhang Y, Dodel R, Farlow MR, Paul PM, Du Y: Minocycline blocks nitric oxide-induced neurotoxicity by inhibition p38 MAP kinase in rat cerebellar granule neurons. Neurosci Lett 200I, 3 I 5:6I-64.

28. Pi R, Li W, Lee NT, Chan HH, Pu Y, Chan LN, Sucher NJ, Chang DC, Li M, Han Y: Inocycline prevents glutamate-induced apoptosis of cerebellar granule neurons by differential regulation of p38 and Akt pathways. I Neurochem 2004, 9 I: I 12 | $9-1230$.

29. Wang J, Wei Q, Wang CY, Hill WD, Hess DC, Dong Z: Minocycline up-regulates $\mathrm{Bcl}-2$ and protects against cell death in mitochondria. I Biol Chem 2004, 279: 19948-19954.

30. Matsuki S, luchi Y, Ikeda Y, Sasagawa I, Tomita Y, Fujii J: Suppression of cytochrome $c$ release and apoptosis in testes with heat stress by minocycline. Biochem Biophys Res Commun 2003, 3 I 2:843-849.

31. Chae IH, Park KW, Kim HS, Oh BH: Nitric oxide-induced apoptosis is mediated by Bax/Bcl-2 gene expression, transition of cytochrome $c$, and activation of caspase-3 in rat vascular smooth muscle cells. Clin Chim Acta 2004, 341:83-9I.

32. Teng YD, Choi H, Onario RC, Zhu S, Desilets FC, Lan S, Woodard EJ, Snyder EY, Eichler ME, Friedlander RM: Minocycline inhibits contusion-triggered mitochondrial cytochrome c release and mitigates functional deficits after spinal cord injury. Proc Natl Acad Sci USA 2004, I 0 I:307 I-3076.

33. Zhu S, Stavrovskaya IG, Drozda M, Kim BY, Ona V, Li M, Sarang S, Liu AS, Hartley DM, Wu DC, Gullans S Ferrante RJ, Przedborski S, Kristal BS, Friedlander RM: Minocycline inhibits cytochrome c release and delays progression of amyotrophic lateral sclerosis in mice. Nature 2002, I 7:74-78

34. Arvin KL, Han BH, Du Y, Lin SZ, Paul SM, Holtzman DM: Minocycline markedly protects the neonatal brain against hypoxicischemic injury. Ann Neurol 2002, 52:54-6I.

35. Wang CX, Yang T, Noor R, Shuaib A: Delayed minocycline but not delayed mild hypothermia protects against embolic stroke. BMC Neurol 2002, 2:2

36. Wang CX, Yang T, Shuaib A: Effects of minocycline alone and in combination with mild hypothermia in embolic stroke. Brain Res 2003, 963:327-969.

37. Xu L, Fagan SC, Waller JL, Edwards D, Borlongan CV, Zheng J, Hill WD, Feuerstein G, Hess DC: Low dose intravenous minocycline is neuroprotective after middle cerebral artery occlusionreperfusion in rats. BMC Neurol 2004, 4:7.

38. Diguet E, Fernagut PO, Wei X, Du Y, Rouland R, Gross C, Bezard E, Tison F: Deleterious effects of minocycline in animal models of Parkinson's disease and Huntington's disease. Eur J Neurosci 2004, 19:3266-3276.

39. Fagan SC, Edwards DJ, Borlongan CV, Xu L, Arora A, Feuerstein G, Hess DC: Optimal delivery of minocycline to the brain: implication for human studies of acute neuroprotection. Exp Neurol 2004, I 86:248-29|.

40. Song Y, Wei EQ, Zhang WP, Zhang WP, Zhang L, Liu JR, Chen Z: Minocycline protects PCI 2 cells from ischemic-like injury and inhibits 5-lipoxygenase activation. Neuroreport 2004, I5:2181-2184.

4I. Yang L, Sugama S, Chirichigno JW, Gregorio J, Lorenzl S, Shin DH, Browne SE, Shimizu Y, Joh TH, Beal MF, Albers DS: Minocycline enhances MPTP toxicity to dopaminergic neurons. J Neurosci Res 2003, 74:278-285.

42. Tsuji M, Wilson MA, Lange MS, Johnston MV: Minocycline worsens hypoxic-ischemic brain injury in a neonatal mouse model. Exp Neurol 2004, 189:58-65. 
43. Werz O, Klemm J, Samuelsson B, Radmark O: 5-lipoxygenase is phosphorylated by $\mathbf{3 8}$ kinase-dependent MAPKAP kinases. Proc Natl Acad Sci USA 2000, 97:526I-5266.

44. Klegeris A, McGeer PL: Cyclooxygenase and 5-lipoxygenase inhibitors protect against mononuclear phagocyte neurotoxicity. Neurobiol Aging 2003, 23:787-794.

45. Bigby TD: The yin and the yang of 5-lipoxygenase pathway activation. Mol Pharmacol 2002, 62:200-202.

46. Wang X, Ellison JA, Siren AL, Lysko PG, Yue TL, Barone FC, Shatzman $A$, Feuerstein GZ: Prolonged expression of interferon-inducible protein- 10 in ischemic cortex after permanent occlusion of the middle cerebral artery in rat. I Neurochem 1998, 7I:II94-I204

47. Cole KE, Strick CA, Paradis TJ, Ogborne KT, Loetscher M, Gladue RP, Lin W, Boyd JG, Moser B, Wood DE, Sahagan BG, Neote K Interferon-inducible T cell alpha chemoattractant (I-TAC): a novel non-ELR CXC chemokine with potent activity on activated $T$ cells through selective high affinity binding to CXCR3. J Exp Med 1998, 187:2009-2021.

48. Sorensen TL, Tani M, Jensen J, Pierce V, Lucchinetti C, Folcik VA, Qin S, Rottman J, Sellebjerg F, Strieter RM, Frederiksen JL, Ransohoff RM: Expression of specific chemokines and chemokine receptors in the central nervous system of multiple sclerosis patients. J Clin Invest 1999, I 03:807-8I5.

49. Flynn G, Maru S, Loughlin J, Romero IA, Male D: Regulation of chemokine receptor expression in human microglia and astrocytes. J Neuroimmunol 2003, 136:84-93.

50. Schroeter M, Jander S, Witte OW, Stoll G: Local immune responses in the rat cerebral cortex after middle cerebral artery occlusion. J Neuroimmunol 1994, 55:195-203.

5I. Loetscher M, Gerber B, Loetscher P, Jones SA, Piali L, Clark-Lewis I, Baggiolini $M$, Moser $B$ : Chemokine receptor specific for IPIO and mig: structure, function, and expression in activated $T$. lymphocytes. J Exp Med 1996, I 84:963-969.

52. Cartier L, Hartley O, Dubois-Dauphin M, Krause KH: Chemokine receptors in the central nervous system: role in brain inflammation and neurodegenerative diseases. Brain Res Rev 2005, 48: $16-42$.

53. Borlongan CV, Yamamoto M, Takei N, Kumazaki M, Ungsuparkorn C, Hida $H$, Sanberg PR, Nishino $H$ : Glial cell survival is enhanced during melatonin-induced neuroprotection against cerebral ischemia. FASEB J 2000, | 4: |307-|3|7.

54. Tanaka J, Toku K, Zhang B, Ishihara K, Sakanaka M, Maeda N: Astrocytes prevent neuronal death induced by reactive oxygen and nitrogen species. Glia 1999, 28:85-96.

55. Kraus RL, Pasieczny R, Lariosa-Willingham K, Turner MS, Jiang A, Trauger JW: Antioxidant properties of minocycline: neuroprotection in an oxidative stress assay and direct radicalscavenging activity. J Neurochem 2005, 94:819-827.

56. Yenari MA, Xu L, Tang XN, Qiao Y, Giffard RG: Microglia potentiate damage to blood-brain barrier constituents: improvement by minocycline in vivo and in vitro. Stroke 2006, 37:1087-1093.

57. Gordon PH, Moore DH, Miller RG, Florence JM, Verheijde JL, Doorish C, Hilton JF, Spitalny GM, MacArthur RB, Mitsumoto H, Neville HE, Boylan K, Mozaffar T, Belsh JM, Ravits J, Bedlack RS, Graves MC, McCluskey LF, Barohn RJ, Tandan R;, Western ALS Study Group: Efficacy of minocycline in patients with amyotrophic lateral sclerosis: a phase III randomised trial. Lancet Neurol 2007, 6:1045-1053

58. Malagelada C, Xifro X, Badiola N, Sabrià J, Rodríguez-Álvarez J: Histamine H2-receptor antagonist ranitidine protects against neural death induced by oxygen-glucose deprivation. Stroke 2004, 35:2396-2401.

59. Yasuhara T, Shingo T, Kobayashi K, Yano A, Muraoka K, Matsui T, Miyoshi $Y$, Hamada H, Date I: Neuroprotective effects of vascular endothelial growth factor (VEGF) upon dopaminergic neurons in a rat model of Parkinson's disease. Eur J Neurosci 2004, 19:1494-1504.

60. Borlongan CV, Tajima Y, Trojanowski JQ, Lee VMY, Paul R, Sanberg PR: Transplantation of cryopreserved human embryonal carcinoma-derived neurons (NT2N cells) promotes functional recovery in ischemic rats. Exp Neurol 1998, I49:310-321.

61. Bederson JB, Pitts LH, Tsuji M, Nishimura MC, Davis RL, Bartkowski $\mathrm{H}$ : Rat middle cerebral artery occlusion: evaluation of the model and development of a neurologic examination. Stroke 1986, I 7:472-476.

62. Sanberg PR, Borlongan CV, Othberg AI, Saporta S, Freeman TB, Cameron DF: Testis-derived Sertoli cells have a trophic effect on dopamine neurons and alleviate hemiparkinsonism in rats. Nat Med 1997, 3: I I29-I I 32.

63. Bederson JB, Pitts LH, Germano SM, Nishimura MC, Davis RL, Bartkowski HM: Evaluation of 2,3,5-triphenyltetrazolium chloride as a stain for detection and quantification of experimental cerebral infarction in rats. Stroke 1986, I 7: |304- |308.

64. Walder CE, Green SP, Darbonne WC, Mathias J, Rae J, Dinauer MC, Curnutte JT, Thoma GR: Ischemic stroke injury is reduced in mice lacking a functional NADPH oxidase. Stroke 1997, 28:2252-2258.

65. Wang Y, Chang CF, Morales M, Chiang YH, Hoffer J: Protective effects of glial cell line-derived neurotrophic factor in ischemic brain injury. Ann N Y Acad Sci 2002, 962:423-437.

66. Abercrombie M, Johnson ML: Quantitative histology of Wallerian degeneration $I$. Nuclear population in rabbit sciatic nerve. J Anat 1946, 80:37-50.

67. Matsukawa N, Tooyama I, Kimura H, Yamamoto T, Tsugu Y, Oomura Y, Ojika K: Increased expression of hippocampal cholinergic neurostimulating peptide-related components and their messenger RNAs in the hippocampus of aged senescenceaccelerated mice. Neuroscience 1999, 88:79-92.

68. Paxinos GW, Watson C: The Rat Brain in Stereotaxic Coordinates. San Diego: Academic Press; 1986.
Publish with Biomed Central and every scientist can read your work free of charge

"BioMed Central will be the most significant development for disseminating the results of biomedical research in our lifetime. "

Sir Paul Nurse, Cancer Research UK

Your research papers will be:

- available free of charge to the entire biomedical community

- peer reviewed and published immediately upon acceptance

- cited in PubMed and archived on PubMed Central

- yours - you keep the copyright
BioMedcentral 